\title{
The Concept of Adhyas in Sankar and Post Sankar Vedanta
}

\author{
Dr. Uma Sharma*
}

Keywords: Adhyas and post Sankar

\section{INTRODUCTION}

In any consistence metaphysical system, the three basic ingredients, Methodology, epistemology and ontology must exists harmoniously. The system Sankar Vedanta is closely connected with her non dualistic ontology and its epistemological position clearly implies a strict monism. Moreover, the epistemological issues in Sankar Vedanta have a certain definite contemporary significance. It is also use full to compare the point with the philosophical position of Kant.

The central question which we want to discuss with reference to these three epistemologies is does the act of observation make a difference in the thing or system which is under the observation of an observer? And if this type of epistemology is accepted, can it be saved from a solipstic ontic position? The observer is not merely a passive receiver of the knowledge of the object before him or her. It is remarkable thing that Sankar theory of Adhyasa is one of the most consistent theories in harmony with the rest of Sankar Vedanta.

The theory of Adhyasa needs to be presented very carefully. Is it a simple a theory of Error? Has it some ontological reference also? Let it be made clear by presenting it Sankar own words:

" युष्मदस्मत्प्रत्ययगौचरयोर्विषयविषयणोस्तम :

प्रकाशवद्विरुद्धस्वभावयोरितरेततरभावानुपपतौ

सिद्धायांतद्वर्माणामपि सुतरामितरेतरभावनुपपत्तिः,

इत्यतोऽस्मत्प्रत्ययगोचरे विषयणि चिदात्मके

युष्मत्प्रत्यगोचरस्य विषयसतद्वर्माणां चा ध्यास:,

तदृिर्ययेण विषयाणिस्तद्वमणि च

विषयेऽध्यासो मिथ्यतेभवितुं युकत्म् ,(१)

Sankar starts his Bhasya with a strong position of his philosophy of the opposites. There is the question before SankarAdhyasa or super imposition generally occurs in a situation when two -

*Assistant Professor, Nalini Arts College, SP University, VVN, Anand, India 
-different objects with some characteristics in common are mistakenly taken one for the other. For Example a 'Knower' can have the Adhyasa of 'snake' or the 'rope'. In this example the knowledge of snake is a mistaken knowledge which needs to be replaced by knowledge of rope at the state of true knowledge. However case of the Ahyasas in Sankar Vedanta, the situation is altogether different. The famous example of snake rope is types of Adhyasa. The main Adhyasa is central to Sankar Vedanta is the Adhyasa of 'ego' and 'non ego' or the combination of concept of the 'Asmat' and 'Yusamat' on the same 'Pratyagatama' (or natural or pure consciousness).

Here the opposition raises a meaningful question about the nature of 'ego' and 'non ego' being quite different. Now in the process of Adhyasa it is not only 'object' which mistakenly taken as otherwise by the 'subject'. Here the opposition is raising a meaningful question: The nature of 'ego' and 'non ego' is quite different. Here rather both 'subject' and 'object' are the part of adhaysa. So here in the back of 'snake' both 'subject' and 'object' are to be put. The role of 'rope' is to be played by 'pratyagatma'. Now how it is possible that subject and object which are having contradictory characteristics like light and darkness can be superimposed on the same pratyagatma ? (in fact this is question before Shankar and not his own view Dr. Radhakrishan takes it as view of Sankar by mistake. $)^{(2)}$ In this question which is accepted by Sankar as a meaningful question before him. There is a important point to be noted.

In Sankar Vedanta the theory of adhyasa not only something about the role of subject and object in an epistemological process. It demands an explanation of this distinction between subject and object on the level of ontology. If Pratygataman that consciousness which know itself purely excluding all the world of empirical phenomena is called pratyagataman. In this pure form of reality how it is possible that two totally distinct type of phenomena are to be superimposed on the same pratyagataman.

The answer to this question, as if naturally appears cannot be achieved in the frame work of epistemology. If we are not considering the nature of reality itself, it is not possible to give and answer to this question.

The answer given by Sankar and adheres further by Vacaspati is the concept of Anirvachaniyattva which must necessarily intervene. Vacaspati takes a hold stand and declares that Anirvachaniyattva is not simplify a position accepted in Sankar Vedanta, rather it is a sarvatantrasiddhant or a principal accepted by all philosophical systems. ${ }^{(4)}$

Anirvachaniyattva means the impossibility of any 'deduction' (Nirvachan) from ultimate reality to empirical reality. ${ }^{(5)}$ Vacaspati examines in detail, the position of different philosophical systems that Anirvachaniyattva may be regarded as a common characteristics among all schools of thought so far as the different theories of errors are concerned.

Leaving aside the estimation of this general claim, it can be noted without doubt that Vachaspati is fully consistent when he observe the cause of the Adhyasa in partyagatma to quote he says: 
“सत्यं प्रत्यगात्मास्वंयप्रकाशत्वाद विषयोऽनंशश्च

तथाप्यनिर्वचनीयानाद्यविद्यापरिकल्पित बुद्धि

मनः सूक्ष्मस्थूलशरीरेन्द्रियावच्छेदेनानवच्छिन्नोऽपि

वस्तुतोऽवच्छिन्न इवाभिन्नोऽपि भिन्न इवाकर्तापि

कर्तेवाभोक्तापि भोक्तेवाविषयोऽप्य स्मत्प्रत्ययविषय

इवजीवभावमापन्नोऽवभासते ।"(६)

Vachaspati successfully derives the ontological ground for the justification of the theory of adhyasa :pratyagatma as 'svaymprakasha'. This is term is needed veryimportant. It is a characteristic of reality in Vedanta defined as अवेधत्वसहितअपरोक्ष व्यवहारयोग्यता ${ }^{(7)}$ by Chitsukhacharya in his Chitsukh. This svayamprakashttva of pratyagatma makes it ontological impossible, as it is neutrally implied in its concept that it is part less and transtemporally eternal and that there can be any Real's inposition (or super imposition) of anything it. This is the point where in the role of Anadiavidhya comes to our rescue. This partyagatma or fundamental consciousness appears in the discourse in a way that its entire role remains simply that of a one sided observer. The whole distinction between subject and object which is neutrally observed by a Sankar is to be considered in the realm of Maya.

In this way they may conclude that theory of Adyhyasa in Sankar Vedanta is a necessary ingredient of the entire metaphysical system and implication is Non Dualistic ontology.

\section{REFERENCE:}

1. Brahmasutra Shankar Bhasya 6-15.

2. RadhakrishnaS :indian Philosophy Vol - II Chapter (VII). In the Advaita Vedanta of Shankara.

3. VachapatiBhamti p 36

4. Ibid : SarvatantraSiddhanta is defined by nyaya $\mathrm{p} 33$

5. VachspatiBhamti : (1-1-28)

6. Ibid : p 38

7. Citsukhi : 